\title{
EVALUASI RUTE ANGKUTAN KOTA BERBASIS KEBUTUHAN PERGERAKAN MASYARAKAT DENGAN METODE (GIS) DI KOTA MALANG
}

\author{
Evaluation of Public Tramsportation Based on People Demand With (GIS) Methode In Malang \\ City
}

\author{
Achendri M. K ${ }^{1}$, A. Wicaksono², Agus Suharyanto ${ }^{3}$ \\ 1,2,3 Jurusan Teknik SipilFakultas TeknikUniversitas Brawijaya \\ Alamat korespondensi : Jln. MT. Haryono, Malang, Jatim \\ e-mail: ${ }^{1)}$ achendri.ac@Gmail.com
}

\begin{abstract}
The problem of public transport in the city of Malang have much affect on the city, to prevent public transport issues are more complex, it is essential to be anticipated as early as possible with the "Evaluation of City Transportation These Movement Needs a Community-Based Methods ( GIS ) in Malang “. The total area of these villages through which the TST area of $36.86 \mathrm{~km} 2$. Broad coverage area of $25.41 \mathrm{~km} 2$. Broad coverage area clean without overlapping area of $11.68 \mathrm{~km} 2$ . The results show that the overlay area unserved area of $11.45 \mathrm{~km} 2$. The majority of the people on the TST still willing to use public transportation with a maximum distance of $200 \mathrm{~m}$. The total area through which the village area of $21.325 \mathrm{~km} 2$ route ABH. Broad coverage area of $19.12 \mathrm{~km} 2$. Broad coverage area clean without overlapping area of $0 \mathrm{~km} 2$. So the overlay results show that the area of the unserved area of $2.208 \mathrm{~km} 2$. The majority of the people on the route ABH still willing to use public transportation with a maximum distance of $100 \mathrm{~m}$. The total area through which the village area of $12.998 \mathrm{~km} 2 \mathrm{HM}$ service. Broad coverage area of $11.87 \mathrm{~km} 2$. Broad coverage area clean without overlapping area of $1,496 \mathrm{~km} 2$. So the overlay results show that the vast area covering 1,123 km2 unserved. Communities on the route HM still willing to use public transportation with a maximum distance of $200 \mathrm{~m}$.
\end{abstract}

Key Word : GIS, coverage area, overlapping area, route

\begin{abstract}
Abstrak
Masalah angkutan umum di Kota Malang telah banyak mempengaruhi kegiatan kota, untuk mencegah timbulnya permasalahan angkutan umum yang lebih kompleks lagi, maka perlu kiranya diantisipasi sedini mungkin dengan "Evaluasi Rute Angkutan Kota Berbasis Kebutuhan Pergerakan Masyarakat Dengan Metode (GIS) Di Kota Malang”. Luas wilayah kelurahan yang dilalui rute TST seluas $36,86 \mathrm{~km}^{2}$. Luas coverage area $25,41 \mathrm{~km}^{2}$. Luas coverage area bersih tanpa adanya overlapping seluas $11,68 \mathrm{~km}^{2}$. Hasil overlay menunjukkan bahwa luas area yang belum terlayani seluas $11,45 \mathrm{~km}^{2}$. Mayoritas masyarakat pada rute TST masih bersedia menggunakan angkot dengan jarak maksimal $200 \mathrm{~m}$. Luas wilayah kelurahan yang dilalui rute $\mathrm{ABH}$ seluas $21,325 \mathrm{~km} 2$. Luas coverage area $19,12 \mathrm{~km}^{2}$. Luascoverage area bersih tanpa adanya overlapping seluas $0 \mathrm{~km} 2$. Sehingga hasil overlay menunjukkan bahwa luas area yang belum terlayani seluas 2,208 km2. Mayoritas masyarakat pada rute ABH masih bersedia menggunakan angkot dengan jarak maksimal 100m. Luas wilayah kelurahan yang dilalui rute $\mathrm{HM}$ seluas 12,998 $\mathrm{km}^{2}$. Luas coverage area $11,87 \mathrm{~km}^{2}$. Luas coverage area bersih tanpa adanya overlapping seluas $1,496 \mathrm{~km}^{2}$. Sehingga hasil overlay menunjukkan bahwa luas area yang belum terlayani seluas $1,123 \mathrm{~km}^{2}$. Masyarakat pada rute HM masih bersedia menggunakan angkot dengan jarak maksimal $200 \mathrm{~m}$.
\end{abstract}

Kata kunci : GIS, urban sprawl, transportation, route

\section{PENDAHULUAN}

Pada saat ini, kota-kota di dunia termasuk Indonesia mengalami perkembangan yang sangat pesat. Perkembangan tersebut disebabkan oleh jumlah penduduk kota yang semakin meningkat dan aktivitas yang dilakukan penduduk tersebut semakin tinggi. Pertumbuhan jumlah penduduk yang tinggi di kota Malang dengan Laju pertumbuhan penduduk Kota Malang per tahun selama sepuluh tahunterakhir 
yakni dari tahun 2000-2010 sebesar 0,80 persen. Laju pertumbuhanpenduduk Kecamatan Kedungkandang adalah yang tertinggi dibandingkankecamatan lain di Kota Malang yakni sebesar 1,50 persen, diikuti KecamatanSukun 1,12 persen, Kecamatan Lowokwaru 0,99 persen, Kecamatan Blimbing0,82 persen dan Kecamatan Klojen -1,02 persenmenyebabkan terjadinya peningkatan jumlah pergerakan. Namun hal ini masih terkendala dengan pemukiman padat penduduk yang tidak merata, sehingga di daerah tertentu belum terlayani oleh angkutan kota. BPS Kota Malang (2010).

Dishub Kota Malang mengatakan Transportasimerupakan sarana dalam memperlancar roda perekonomian serta mempermudah pergerakan penduduk dan barang. Salah satu sarana transportasi yaitu sarana transportasi darat yang meliputi angkutan umum dan kendaraan pribadi, dimana penggunaan kendaraan pribadi lebih dominan dibandingkan angkutan umum setiap tahunnya pertumbuhan kendaraan bermotor meningkat sampai $13 \%$, pertumbuhan ini terdiri dari $10 \%$ peningkatan sepedah motor dan mobil meningkat hingga 3\% pertahunnya. Berdasarkan data dinas perhubungan kota malang jumlah motor pada tahun 2005 lalu mencapai 173.000 unit sedangkan pemilik mobil pada tahun yang sama mencapai 63000 unit.

Salah satu akibat dari buruknya keterpaduan pelayanantransportasi umum di kota Malang adalah waktu dan biaya perjalanan makin tinggi, dan dampaknya adalah perjalanan menjadi melelahkan bagi pengguna angkutan kota. Minimnya fasilitas perpindahan dan rendahnya tingkat pelayanan keterpaduan antar moda transportasi perkotaan mengakibatkan pelaku perjalalanan lebih memilih menggunakan kendaraan pribadi, sehingga meningkatkan volume lalulintas di perkotaan, menurunnya keselamatan lalulintas, dan pemborosan penggunaan bahan bakar serta meningkatkan polusi udara dan suara.Sistem angkutan kota adalah bagian penting dari kehidupan perkotaan modern. Di beberapa Negara maju, Angkutan kota sudah menjadi pilihan utama dalam melakukan aktivitas perjalanan., karena telah dirancang dengan baik sehingga system transportasi telah terintegrasi dengan moda transportasi lain. Hal tersebut memudahkan masyarakat untuk melakukan perjalanan untuk aktivitas sehari-hari. Hal lainnya adalah berkurangnya dampak penggunaan kendaraan pribadi karena lebih efisien dan efektif dibandingkandenganmenggunakan kendaraan pribadi.

Dari uraian di atas maka tujuan penelitian ini adalah :

- Mengetahui kinerja rute eksisting angkutan kota TST, ABG dan GM di Kota Malang

- Mengetahuipergerakan masyarakat kota Malang pada rute TST, ABG dan GM

- Mengetahuikinerja rute eksisting berbasis kebutuhan pergerakan masyarakat kota malang pada rute TST, ABG dan GM dengan menggunakan analisisGIS.

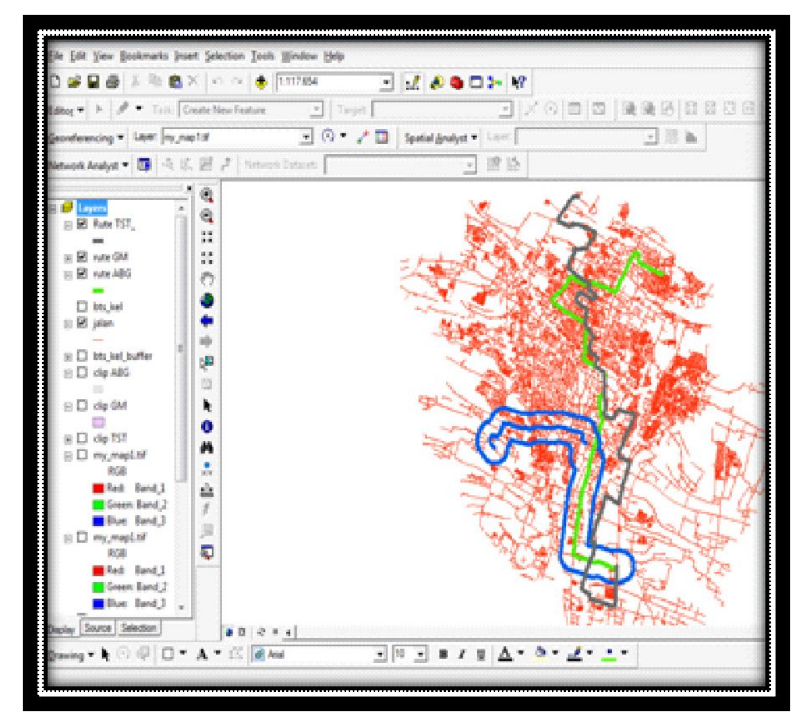

Gambar 1. Aplikasi Perangkat Lunak GIS dan Rute Angkutan Kota yang Diteliti

\section{METODE PENELITIAN}

\section{Metode Analisa Data}

- Analisa Pola Perkembangan Kota Dan Penggunaan Lahan: Analisa ini dilakukan untuk mengidentifikasi kondisi eksisting Kota Malang yang dilihat dari pola perkembangan Kota Malang, pola perjalanan, permintaan akan angkutan kota dan pelayanan rute angkutan kota. Analisa ini dilakukan menurut data hasil survei melalui wawancara rumah tangga (home interview) dan data lain yang diperoleh dalam penelitian ini.

- Analisa Bangkitan Pergerakan (Trip Genertion) atau Pola Pergerakan: Analisa pola 
pergerakan ini dilakukan untuk mengetahui potensi pergerakan yang ada di Kota Malang sehubungan dengan guna lahan dan jumlah penduduk saat ini pada angkutan kota.

- Analisa Permintaan Angkutan Kota: Analisa permintaan akan angkutan kota dimaksudkan untuk mengetahui besaran pergerakan, distribusi pergerakan, dan tujuan pergerakan.

- Analisa Sistem Jaringan Jalan Angkutan Kota: Analisis ini dilakukan untuk mengetahui karakteristik jaringan jalan di Kota Malang dan kondisi jaringan jalan rute angkutan kota di Kota Malang saat ini.

- Analisis Pelayanan Rute Angkutan Kota: Analisis ini dilakukan untuk mengidentifikasi trayek-trayek angkutan kota yang ada di Kota Malang. Pelayanan transportasi angkutan kota dalam kota pada semua rute angkutan kota menjadikan pusat kota sebagai tujuan akhir perjalanan, karena kawasan pusat kota merupakan pusat kegiatan perkantoran (pemerintah dan swasta), perdagangan, permukiman, wisata, pendidikan dan pasar regional. Sehingga pola rute yang ada, hanya menghubungkan zona pusat kota dengan zona pinggir kota. Masih sedikitnya rute trayek yang menghubungkan langsung antara zona pinggir kota tanpa harus melalui zona pusat kota.

- Analisa Kinerja Angkutan Kota: Angkutan kota di selenggarakan untuk memberikan pelayanan yang optimal kepada masyarakat pengguna jasa angkutan kota. Untuk itu beberapa kriteria umum dalam penilaian unjuk kerja angkutan kota perlu di lakukan untuk mengetahui apakah oerasional angkutan kota yang ada telah memenuhi standar atau rekomendasi yang ada.

- Analisa Kebutuhan Angkutan Kota: Mengingat fluktuasi arus penumpang maupun angkutan kota dan lalu lintas agar penumpang, operator, dan para pengguna jalan lainnya tidak saling dirugikan maka perlu di tempuh suatu cara untuk dapat mengatasinya. Dari pihak penumpang tidak ingin di rugikan perjalanannya tertunda ataupun terlambat, sementara pengusaha jasa angkutan kota ataupun operator tidak ingin mengoperesikan angkutan dengan faktor muat yang rendah. Waktu yang terbuang di perjalanan dan waktu menunggu merupakan kerugian karena di samping menjemukan juga melelahkan, sementara itu di pihak pengguna jalan lainnya menghendaki arus lalu lintas yang lancar terutama pada jam-jam sibuk. Oleh karena itu perlu di tempuh cara cara operasi kendaraan angkutan kota terutama pada jam sibuk. Sehingga dapat di sediakan armada yang seimbang dengan jumlah permintaan.

- Analisa penentuan pelayanan angkutan kota dari wilayah potensial yang tidak terlayani: Analisis penentuan pelayanan angkutan kota dari zona potensial yang dimaksud disini adalah zona-zona yang termasuk dalam hirarki serta kepadatan yang cukup tinggi namun karena luas cakupan dari buffer atau jangkauan sesuai standar yang dilakukan tidak terlayani secara keseluruhan, maka dibangun suatu analisis baru yang kaitannya untuk mengakomodasi terhadap tindakan penyelesaian permasalahan dengan menempatkan hasil output berupa wilayah yang kurang terlayani tersebut untuk direncanakan penempatan angkutan tipe kecil. Alternatif moda yang masuk kedalam kategori adalah moda yang memilki kapasitas angkut yang kecil hingga sedang. Adapun alternatif moda yang mungkin diterapkan untuk jalur feeder yaitu ojek, becak, bajaj.

- Analisa Perangkat Lunak GIS: Analisa ini digunakan sebagai pusat data base hasil analisa di atas dimulai dari analisa kinerja angkutan sampai analisa penentuan pelayanan angkutan kota dari wilayah pontensial yang belum terlayani dalam bentuk spasial. Selain itu analisa ini digunakan untuk mengetahui guna lahan daerah daerah yang berpotensi menjadi daerah yang masyarakatnya menggunakan angkutan kota. Untuk mengetahui proses lebih lanjut mengenai analisa ini maka dapat dilihat di bawah ini: 


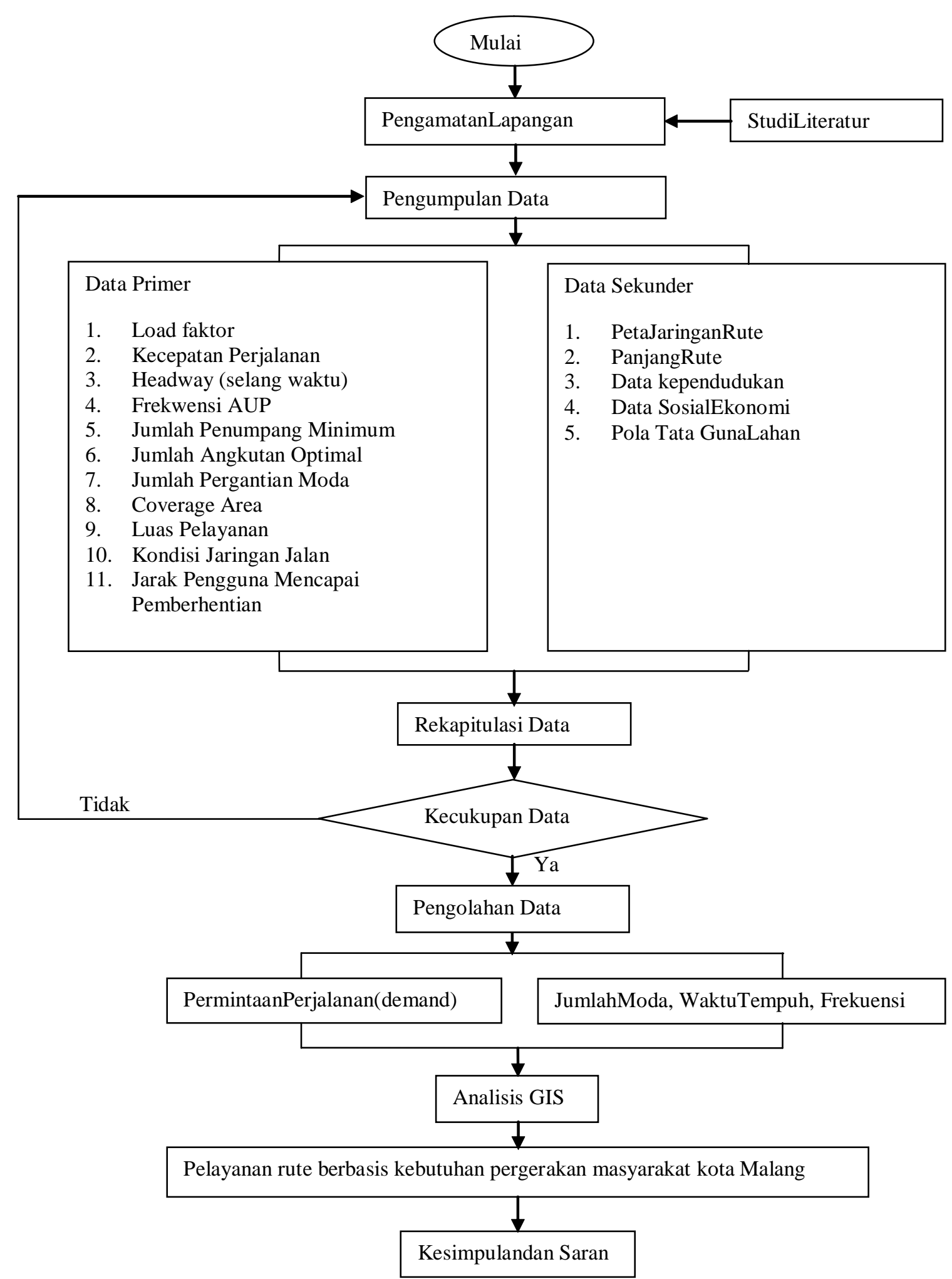

Gambar 2. Diagram Metode Penelitian

\section{HASIL DAN PEMBAHASAN}

\section{Hasil Analisa Pada Rute TST}

Pola pergerakan pengguna angkot TST
Berdasarkan Gambar 3 dapat dilihat bahwa kecamatan yang paling berpotensi sebagai kecamatan tujuan perjalanan pada rute TST (kecamatan penarik terbesar) dengan menggunakan angkutan kota adalah Kecamatan Kedungkandang. Kecamatan Kedungkandang merupakan kawasan 
industri polutif ringan dan pergudangan, terminal terpadu, perdagangan dan jasa serta pemukiman. dengan jumlah perjalanan sebesar 50,355\% dari seluruh perjalanan dengan menggunakan angkutan kota. Pemanfaatan lahan di Kecamatan Kedungkandang tersebut didominasi oleh perdagangan dan jasa serta pemukiman. Kecamatan penarik lainnya adalah Kecamatan Blimbing sebesar $20.567 \%$ dan disusul oleh Kecamatan Klojen sebesar 15,603\% serta Kecamatan Sukun sebesar $13,475 \%$ dari seluruh perjalanan dalam kota dengan menggunakan angkutan kota.

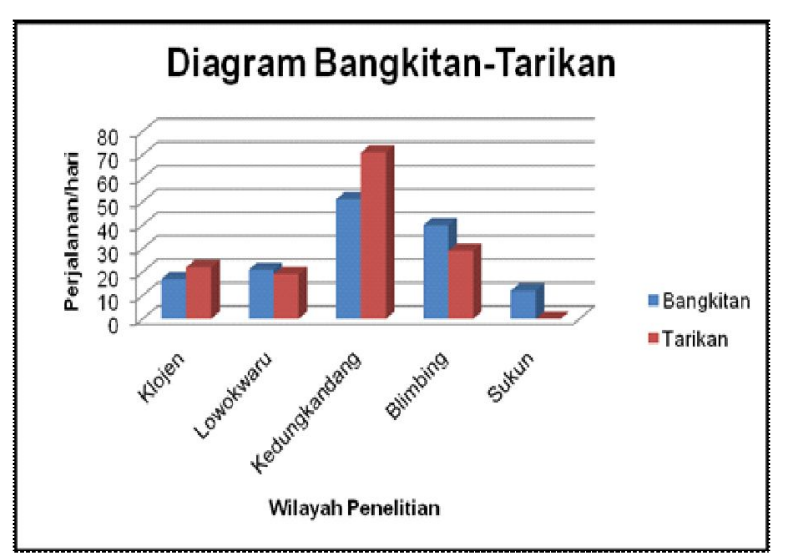

\section{Analisa Pelayanan Rute Angkutan Kota Pada Rute TST}

Berdasarkan analisa Pelayanan Rute dapat dijelaskan bahwa terdapat jalan yang mengalami overlay dengan angkot TST sebanyak 8 angkot termasuk TST yang melewati yaitu Jalan PB. Sudirman, ada angkot yang overlay perjalanan pulang pergi dan ada yang overlay hanya dalam satu kali perjalanan baik itu perjalanan pulang ataupun perjalanan pergi. Angkot yang mengalami overlay pada saat perjalanan pulang pergi pada Jalan PB. Sudirman yaitu TST, AMH, ADL, ABH, AT, dan HA. Sedangkan yang hanya overlay saat perjalanan pulang saja yaitu AL dan AJH. Sehingga wilayah atau area atau kecamatan yang terdapat overlaping tinggi akan mengurangi load factor. Hal ini dikarenakan masyarakat di daerah tersebut langsung mendapatkan pelayanan angkot lebih dari satu trayek tanpa harus mengalami perpindahan angkot.

\section{Jangkauan Pelayanan Angkutan Kota Terhadap Daerah Sekitar Rute TST}

Gambar 3. Bangkitan Tarikan Pengguna Angkot Rute TST

Tabel 1. Coverage Area

\begin{tabular}{|c|c|c|c|c|c|c|}
\hline No & Rute & $\begin{array}{l}\text { Luas } \\
\text { Wilayah }\end{array}$ & $\begin{array}{l}\text { Panjang } \\
\text { Rute }\end{array}$ & $\begin{array}{l}\text { Rute } \\
\text { Overlaping }\end{array}$ & $\begin{array}{l}\text { Coverage } \\
\text { Area }\end{array}$ & $\begin{array}{l}\text { Coverage } \\
\text { Area }\end{array}$ \\
\hline & Angkot & $\left(\mathrm{Km}^{2}\right)$ & $(\mathrm{Km})$ & $(\mathrm{Km})$ & $\left(\mathrm{Km}^{2}\right)$ & $\left(\mathrm{Km}^{2}\right)$ \\
\hline 1 & TST & 36,86 & 25,41 & 13,72 & 25,41 & 13,72 \\
\hline \multicolumn{6}{|c|}{ Besarnya Coverage Area } & 25,41 \\
\hline \multicolumn{6}{|c|}{ Besarnya Coverage Area akibat Overlaping } & 13,72 \\
\hline \multicolumn{6}{|c|}{ Besarnya Coverage Area rute angkot dikurangi overlaping } & 11,68 \\
\hline \multicolumn{6}{|c|}{ Luas wilayah yang dilalui Angkot } & 36,86 \\
\hline \multicolumn{6}{|c|}{ Luas Wilayah yang belum terlayani } & 11,45 \\
\hline
\end{tabular}

Berdasarkan Tabel 1 diatas dapat dijelaskan bahwa luas wilayah kelurahan yang dilalui rute TST seluas $36,86 \mathrm{~km} 2$ dengan coverage area $(500 \mathrm{~m}$ kekanan dan kekiri sepanjang rute angkot) seluas $25,41 \mathrm{~km} 2$. Adapun luas wilayah yang dilalui oleh angkot selain TST (overlapping area) seluas 13,72 $\mathrm{km} 2$ dengan coverage area bersih tanpa adanya overlapping seluas $11,68 \mathrm{~km} 2$. Sehingga hasil overlay menunjukkan bahwa luas area yang belum terlayani (luas kelurahan dikurangi dengan luas coverage area) seluas $11,45 \mathrm{~km} 2$.

\section{Hasil Analisa Pada Rute ABH}

Pola pergerakan pengguna angkot $\mathrm{ABH}$

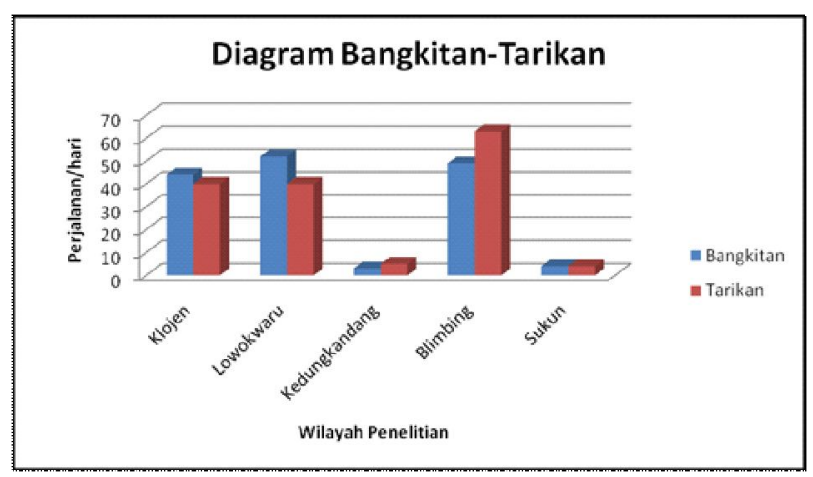

Gambar 4. Bangkitan Tarikan Rute ABH 
Berdasarkan Gambar 4 dapat dilihat bahwa kecamatan yang paling berpotensi sebagai kecamatan tujuan perjalanan pada rute $\mathrm{ABH}$ (kecamatan penarik terbesar) dengan menggunakan angkutan kota adalah Kecamatan Blimbing. Kecamatan Blimbing ini merupakan kawasan Industri kecil dan pergudangan, perdagangan, jasa, pertanian dan pemukiman dengan jumlah perjalanan sebesar $41,45 \%$ dari seluruh perjalanan dengan menggunakan angkutan kota. Kecamatan penarik lainnya adalah Kecamatan Klojen dan Kecamatan Lowokwaru dengan prosentase jumlah nilai yang sama yaitu sebesar 26,32\% dan disusul oleh Kecamatan Kedungkandang sebesar 3,29\% serta Kecamatan Sukun sebesar 2,63\% dari seluruh perjalanan dalam kota dengan menggunakan angkutan kota.

\section{Analisa Pelayanan Rute Angkutan Kota Pada Rute ABH}

Berdasarkan pada analisa Pelayanan Rute dapat dijelaskan bahwa terdapat jalan yang mengalami overlay dengan angkot $\mathrm{ABH}$ sebanyak 10 angkot termasuk $\mathrm{ABH}$ yang melewati yaitu Jalan Raden Intan, ada angkot yang overlay perjalanan pulang pergi dan ada yang overlay hanya dalam satu kali perjalanan baik itu perjalanan pulang ataupun perjalanan pergi. Angkot yang mengalami overlay pada saat perjalanan pulang pergi pada Jalan Raden Intan yaitu ABH, ABB, AT, AH, HA, ASD, AMH, AJH dan ADL. Sedangkan yang hanya overlay saat perjalanan pulang saja yaitu $\mathrm{AL}, \mathrm{AJH}, \mathrm{AMH}, \mathrm{MT}$, AT, ADL dan HA dan yang hanya overlay saat perjalanan pergi saja yaitu MT di Jalan J.G. Subroto. Sehingga wilayah atau area atau kecamatan yang terdapat overlaping tinggi akan mengurangi load factor. Hal ini dikarenakan masyarakat di daerah tersebut langsung mendapatkan pelayanan angkot lebih dari satu trayek tanpa harus mengalami perpindahan angkot.

\section{Jangkauan Pelayanan Angkutan Kota Terhadap Daerah Sekitar Rute ABH}

Tabel 2. Coverage Area

\begin{tabular}{|c|c|c|c|c|c|c|}
\hline No & Rute & Luas Wilayah & Panjang Rute & Rute Overlaping & Coverage Area : & overage Area Overla: \\
\hline & Angkot & $(\mathrm{Km} 2)$ & $(\mathrm{Km})$ & $(\mathrm{Km})$ & $(\mathrm{Km} 2)$ & $(\mathrm{Km} 2)$ \\
\hline 1 & $\mathrm{ABH}$ & 21.326 & 19.118 & 19.118 & 19.118 & 19.118 \\
\hline \multicolumn{6}{|c|}{ Besarnya Coverage Area } & 19.118 \\
\hline \multicolumn{6}{|c|}{ Besarnya Coverage Area Akibat Overlaping } & 19.118 \\
\hline \multicolumn{6}{|c|}{ Besarnya Coverage Area rute angkot dikurangi overlaping } & 0 \\
\hline \multicolumn{6}{|c|}{ Luas Wilayah Yang di Lalui Angkot } & 21.326 \\
\hline \multicolumn{6}{|c|}{ Luas Wilayah Yang Belum Terlayani } & 2.208 \\
\hline
\end{tabular}

Berdasarkan Tabel 2 diatas dapat jelaskan bahwa luas wilayah kelurahan yang dilalui rute ABH seluas $21,325 \mathrm{~km}^{2}$ dengan coverage area (500m kekanan dan kekiri sepanjang rute angkot) seluas 19,118 $\mathrm{km}^{2}$, luas wilayah yang dilalui oleh angkot selain $\mathrm{ABH}$ (overlapping area) seluas $19,118 \mathrm{~km}^{2}$ dengan coverage area bersih tanpa adanya overlapping seluas $0 \mathrm{~km} 2$. Hasil overlay menunjukkan bahwa luas area yang belum terlayani (luas kelurahan dikurangi dengan luas coverage area) seluas 2,208 $\mathrm{km}^{2}$.

Hasil Analisa Pada Rute HM

Pola pergerakan pengguna angkot HM

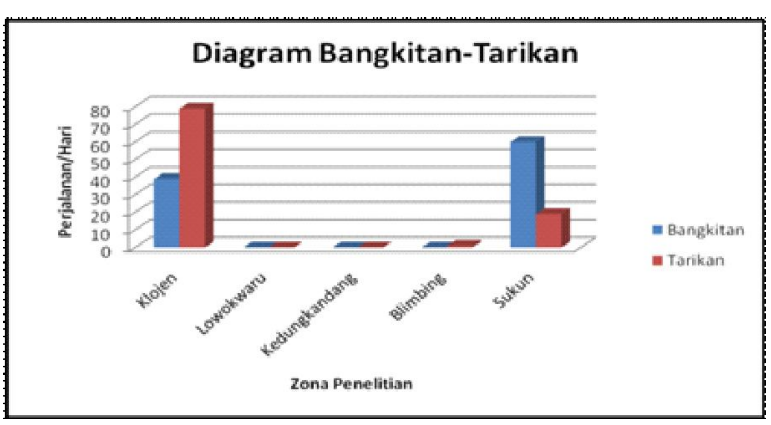

Gambar 5. Bangkitan Tarikan Rute HM
Berdasarkan Gambar 5 dapat dilihat bahwa kecamatan yang paling berpotensi sebagai kecamatan tujuan perjalanan pada rute HM (kecamatan penarik terbesar) dengan menggunakan angkutan kota adalah Kecamatan Klojen. Kecamatan Klojen sebagian besar merupakan kawasan pusat kota yang terdiri dari pusat pemerintahan dan perkantoran, perdagangan dan jasa, sosial budaya, pemukiman dan pariwisata, dengan jumlah perjalanan sebesar $79,79 \%$ dari seluruh perjalanan dengan menggunakan angkutan 
kota. Pemanfaatan lahan di Kecamatan Klojen tersebut didominasi oleh perdagangan dan jasa serta pemukiman. Kecamatan penarik lainnya adalah Kecamatan Sukun sebesar 19,19\% dan disusul oleh Kecamatan Blimbing sebesar 1,01\% dari seluruh perjalanan dalam kota dengan menggunakan angkutan kota.

\section{Analisa Pelayanan Rute Angkutan Kota Pada Rute HM}

Berdasarkan pada analisa dapat dijelaskan bahwa terdapat jalan yang mengalami overlay dengan angkot HM sebanyak 10 angkot termasuk HM yang melewati yaitu Jalan Hamid Rusdi, ada angkot yang overlay perjalanan pulang pergi dan ada yang overlay hanya dalam satu kali perjalanan baik

itu perjalanan pulang ataupun perjalanan pergi. Angkot yang mengalami overlay pada saat perjalanan pulang pergi pada Jalan Raden Intan yaitu HM, HL, HA, AMH, AJH, ABH, AH, LDH, LH, dan HML. Sedangkan yang hanya overlay saat perjalanan pulang saja yaitu HA, AH, MK, MT dan LDH. Sedangkan yang hanya overlay saat perjalanan pergi saja yaitu HML saja. Sehingga wilayah atau area atau kecamatan yang terdapat overlaping tinggi akan mengurangi load factor. Hal ini dikarenakan masyarakat di daerah tersebut langsung mendapatkan pelayanan angkot lebih dari satu trayek tanpa harus mengalami perpindahan angkot.

\section{Jangkauan Pelayanan Angkutan Kota Terhadap \\ Daerah Sekitar Rute HM}

Tabel 3.Coverage Area

\begin{tabular}{|c|c|c|c|c|c|c|}
\hline No & Angkot & $\begin{array}{c}\text { Luas } \\
\text { Wilayah } \\
(\mathrm{Km} 2)\end{array}$ & $\begin{array}{c}\text { Panjang } \\
\text { Rute } \\
(\mathrm{Km})\end{array}$ & $\begin{array}{c}\text { Rute } \\
\text { Overlaping } \\
(\mathrm{Km})\end{array}$ & $\begin{array}{l}\text { Coverage } \\
\text { Area } \\
(\mathrm{Km} 2)\end{array}$ & $\begin{array}{l}\text { Coverage } \\
\text { Area } \\
\text { Overlay } \\
(\mathrm{Km} 2)\end{array}$ \\
\hline 1 & $\mathrm{HM}$ & 12.998 & 11.875 & 10.379 & 11.875 & 10.379 \\
\hline \multicolumn{6}{|c|}{ Besarnya Coverage Area } & 11.875 \\
\hline \multicolumn{6}{|c|}{ Besarnya Coverage Area Akibat Overlaping } & 10.379 \\
\hline \multicolumn{6}{|c|}{ Besarnya Coverage Area rute angkot dikurangi overlaping } & 1.496 \\
\hline \multicolumn{6}{|c|}{ Luas Wilayah Yang di Lalui Angkot } & 12.998 \\
\hline \multicolumn{6}{|c|}{ Luas Wilayah Yang Belum Terlayani } & 1.123 \\
\hline
\end{tabular}

Berdasarkan Tabel 3 diatas dapat jelaskan bahwa luas wilayah kelurahan yang dilalui rute HM seluas 12,998 km2 dengan coverage area $(500 \mathrm{~m}$ kekanan dan kekiri sepanjang rute angkot) seluas $11,875 \mathrm{~km} 2$, luas wilayah yang dilalui oleh angkot selain HM (overlapping area) seluas 10,379 km2 dengan coverage area bersih tanpa adanya overlapping seluas $1,496 \mathrm{~km} 2$. Sehingga hasil overlay menunjukkan bahwa luas area yang belum terlayani (luas kelurahan dikurangi dengan luas coverage area) seluas $1,123 \mathrm{~km} 2$.

Berdasarkan hasil analisis kondisi rute angkot rute TST,ABH dan HM dapat di resumkan seperti terlihat pada tabel berikut ini:

Tabel 4.Hasil Resume Analisis Angkutan Kota Malang

\begin{tabular}{|c|c|c|c|c|c|c|c|c|c|c|}
\hline No & Rute & $\begin{array}{l}\text { Luas Layanan } \\
\qquad(\mathrm{km} 2)\end{array}$ & $\begin{array}{c}\text { Jarak } \\
\text { Layanan } \\
(\mathrm{m})\end{array}$ & $\begin{array}{c}\text { Coverage } \\
\text { Area } \\
(\mathrm{km} 2)\end{array}$ & $\begin{array}{c}\text { Luas } \\
\text { Layanan } \\
\text { Overlapping } \\
(\mathrm{km} 2)\end{array}$ & $\begin{array}{l}\text { Luas } \\
\text { Layanan } \\
\text { Bersih } \\
(\mathrm{km} 2)\end{array}$ & $\begin{array}{c}\text { Luas } \\
\text { Layanan } \\
\text { Yang } \\
\text { belum } \\
\text { Terlayani } \\
(\mathrm{km} 2)\end{array}$ & $\begin{array}{l}\text { Luas } \\
\text { Jalan } \\
(\mathrm{m} 2)\end{array}$ & $\begin{array}{c}\text { Luas } \\
\text { Kerusakan } \\
\text { jalan }(\mathrm{m} 2)\end{array}$ & $\begin{array}{c}\text { Rata-rata } \\
\text { Jumlah } \\
\text { Penumpang } \\
\text { (hari) }\end{array}$ \\
\hline 1 & TST & 36.86 & 1000 & 25.41 & 13.72 & 11.68 & 11.47 & 133933 & 150.71 & 48 \\
\hline 2 & $\mathrm{ABH}$ & 21.32 & 1000 & 19.12 & 19.12 & 0.00 & 2.21 & 167958 & 37.78 & 377 \\
\hline
\end{tabular}




\begin{tabular}{|c|c|c|c|c|c|c|c|c|c|c|}
\hline No & Rute & $\begin{array}{c}\text { Mayoritas } \\
\text { Jarak } \\
\text { Pengguna } \\
\text { Mencapai } \\
\text { Pemberhentian } \\
\text { (m) }\end{array}$ & $\begin{array}{l}\text { Mayoritas } \\
\text { Jumlah } \\
\text { Pergantian } \\
\text { Moda }\end{array}$ & $\begin{array}{l}\text { Waktu } \\
\text { Tempuh } \\
\text { (menit) }\end{array}$ & $\begin{array}{l}\text { Kecepatan } \\
\text { (menit) }\end{array}$ & $\begin{array}{l}\text { Frekwensi } \\
\text { (kend/jam) }\end{array}$ & $\begin{array}{l}\text { Headway } \\
\text { (menit) }\end{array}$ & $\begin{array}{l}\text { Waktu } \\
\text { sirkulasi } \\
\text { (menit) }\end{array}$ & $\begin{array}{c}\text { Load } \\
\text { Faktor }(\%)\end{array}$ & $\begin{array}{c}\text { Kebutuhan } \\
\text { Angkutan } \\
\text { Optimal } \\
\text { (unit) }\end{array}$ \\
\hline 1 & TST & 200 & 0.00 & 108.75 & 17.94 & 3 & 20.10 & 251.28 & 25.50 & 16 \\
\hline 2 & $\mathrm{ABH}$ & 100 & 0.00 & 57.25 & 24.31 & 23 & 2.43 & 131.68 & 31.00 & 60 \\
\hline
\end{tabular}

Berdasarkan tabel 4 dapat dijelaskan kinerja angkot pada rute TST,ABH dan HM sesuai dengan parameter penilaian yang telah di dapatkan pada tabel tersebut, maka dapat disimpulkan seperti pada tabel berikut ini.

Adapun parameter penilaian yang digunakan yaitu laoad faktor, kecepatan perjalanan, hedaway, frekwensi, panjang koridor pengguna masih menggunakan angkot,jumlah penumpang minimum per hari, jumlah minimum angkutan optimal per hari, jumlah pergantian moda atau rute dalam melakukan aktifitas sehari-hari. Parameter penilaian ini di dasarkan pada SK dirjen perhubungan darat tahun 2002.

Kinerja Rute Angkot TST

Tabel 5. Parameter Penilaian Rute Angkot TST

\begin{tabular}{|c|c|c|c|c|c|c|c|}
\hline \multirow[t]{2}{*}{ No } & \multirow[t]{2}{*}{ Parameter Penilaian } & \multirow[t]{2}{*}{ Satuan } & \multicolumn{3}{|c|}{ Standart Penilaian } & \multirow{2}{*}{$\begin{array}{l}\text { Hasil } \\
\text { Penilaian } \\
\text { Angkot }\end{array}$} & \multirow[t]{2}{*}{ Kriteria } \\
\hline & & & Kurang & Sedang & Baik & & \\
\hline 1 & Load Factor & $\%$ & $<70$ & 70 & $>70$ & 25.50 & Kurang \\
\hline 2 & Kecepatan Perjalanan & $\mathrm{km} / \mathrm{jam}$ & $<10$ & $\begin{array}{c}10 \text { sampai } \\
12 \\
10 \text { sampai }\end{array}$ & $>12$ & 17.94 & Baik \\
\hline 3 & Headway & menit & $>20$ & 20 & $<10$ & 20.10 & Kurang \\
\hline 4 & Frekwensi & $\mathrm{kend} / \mathrm{jam}$ & $<4$ & 4 sampai 6 & $>6$ & 3.00 & Baik \\
\hline 5 & Koridor & $\mathrm{m}$ & $>500$ & $300-500$ & $<300$ & 200.00 & Baik \\
\hline 6 & $\begin{array}{l}\text { Jumlah Penumpang } \\
\text { Minimum }\end{array}$ & per hari & $<250$ & $250-300$ & $>300$ & 48.00 & Kurang \\
\hline 7 & $\begin{array}{l}\text { Jumlah Minimum } \\
\text { Angkutan }\end{array}$ & unit & $<20$ & 20 & $>20$ & 16.00 & Kurang \\
\hline 8 & Pergantian Rute & & 2 & $0-1$ & 0 & 0.00 & Baik \\
\hline
\end{tabular}

\section{Kinerja Rute Angkot TST}

Tabel 6. Parameter Penilaian Rute Angkot ABH

\begin{tabular}{|c|c|c|c|c|c|c|c|}
\hline \multirow[t]{2}{*}{ No } & \multirow{2}{*}{ Parameter Penilaian } & \multirow{2}{*}{ Satuan } & \multicolumn{3}{|c|}{ Standart Penilaian } & \multirow{2}{*}{$\begin{array}{c}\text { Hasil } \\
\text { Penilaian } \\
\text { Angkot }\end{array}$} & \multirow[t]{2}{*}{ Kriteria } \\
\hline & & & Kurang & Sedang & Baik & & \\
\hline 1 & Load Factor & $\%$ & $<70$ & 70 & $>70$ & 31.00 & Kurang \\
\hline 2 & Kecepatan Perjalanan & $\mathrm{km} / \mathrm{jam}$ & $<10$ & $\begin{array}{c}10 \text { sampai } \\
12 \\
10 \text { sampai }\end{array}$ & $>12$ & 24.31 & Baik \\
\hline 3 & Headway & menit & $>20$ & 20 & $<10$ & 2.43 & Baik \\
\hline 4 & Frekwensi & kend/jam & $<4$ & 4 sampai 6 & $>6$ & 23.00 & Baik \\
\hline 5 & Koridor & $\mathrm{m}$ & $>500$ & $300-500$ & $<300$ & 100.00 & Baik \\
\hline 6 & $\begin{array}{l}\text { Jumlah Penumpang } \\
\text { Minimum }\end{array}$ & per hari & $<250$ & $250-300$ & $>300$ & 377.00 & Baik \\
\hline 7 & $\begin{array}{l}\text { Jumlah Minimum } \\
\text { Angkutan }\end{array}$ & unit & $<20$ & 20 & $>20$ & 60.00 & Baik \\
\hline 8 & Pergantian Rute & & 2 & $0-1$ & 0 & 0.00 & Baik \\
\hline
\end{tabular}




\section{Kinerja Rute Angkot HM}

Tabel 7. Parameter Penilaian Rute Angkot HM

\begin{tabular}{|c|c|c|c|c|c|c|c|}
\hline \multirow[t]{2}{*}{ No } & \multirow{2}{*}{ Parameter Penilaian } & \multirow[t]{2}{*}{ Satuan } & \multicolumn{3}{|c|}{ Standart Penilaian } & \multirow{2}{*}{$\begin{array}{c}\text { Hasil } \\
\text { Penilaian } \\
\text { Angkot } \\
\end{array}$} & \multirow{2}{*}{ Kriteria } \\
\hline & & & Kurang & Sedang & Baik & & \\
\hline 1 & Load Factor & $\%$ & $<70$ & 70 & $>70$ & 31.30 & Kurang \\
\hline 2 & Kecepatan Perjalanan & $\mathrm{km} / \mathrm{jam}$ & $<10$ & $\begin{array}{c}10 \text { sampai } \\
12 \\
10 \text { sampai }\end{array}$ & $>12$ & 16.88 & Baik \\
\hline 3 & Headway & menit & $>20$ & 20 & $<10$ & 1.83 & Baik \\
\hline 4 & Frekwensi & kend/jam & $<4$ & 4 sampai 6 & $>6$ & 31.00 & Baik \\
\hline 5 & Koridor & $\mathrm{m}$ & $>500$ & $300-500$ & $<300$ & 200.00 & Baik \\
\hline 6 & $\begin{array}{l}\text { Jumlah Penumpang } \\
\text { Minimum }\end{array}$ & per hari & $<250$ & $250-300$ & $>300$ & 506.00 & Baik \\
\hline 7 & $\begin{array}{l}\text { Jumlah Minimum } \\
\text { Angkutan }\end{array}$ & unit & $<20$ & 20 & $>20$ & 30.00 & Baik \\
\hline 8 & Pergantian Rute & & 2 & $0-1$ & 0 & 0.00 & Baik \\
\hline
\end{tabular}

Tabel 8. Pergerakan Masyarakat

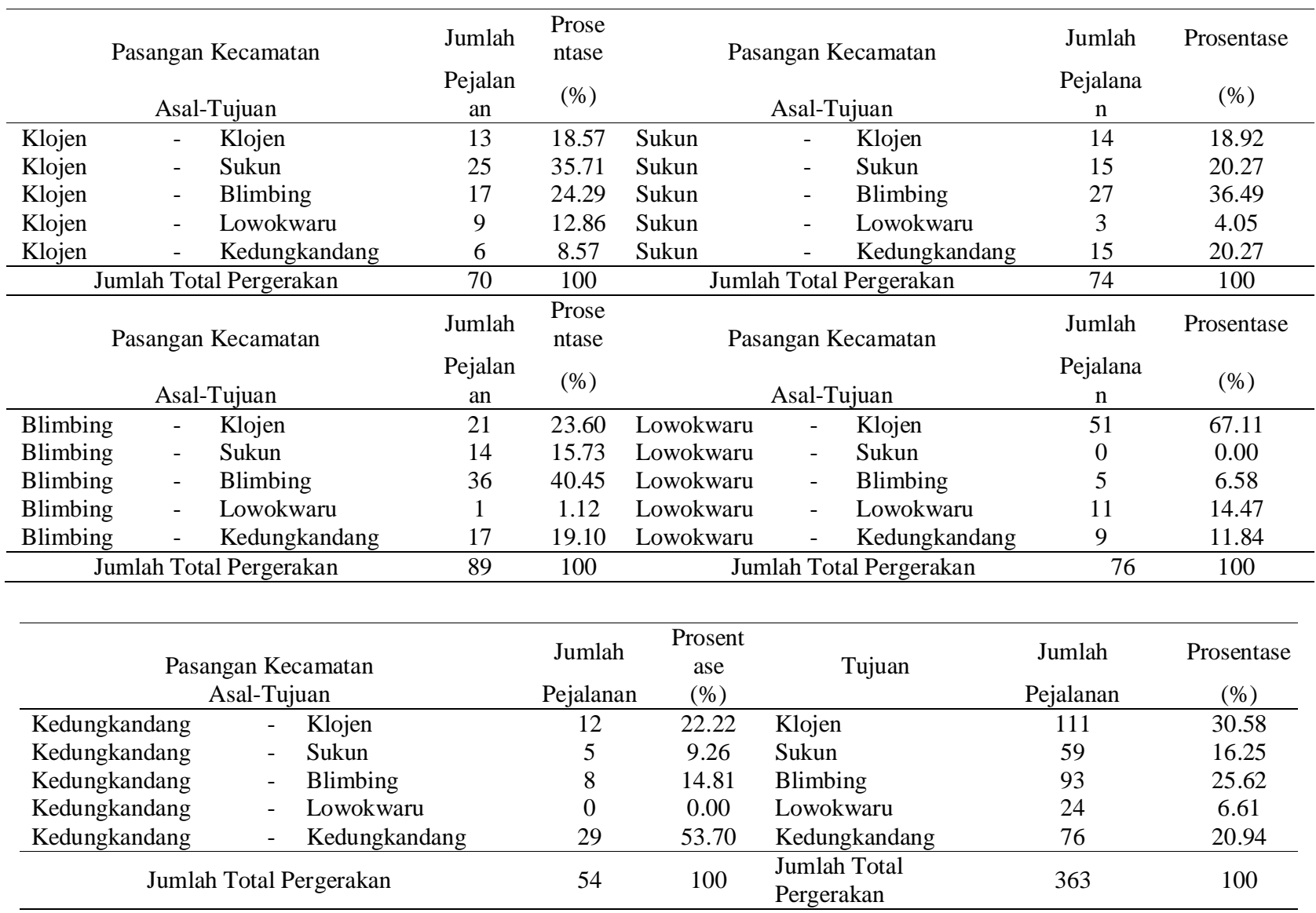

Mayoritas pergerakan masyarakat kecamatan kedungkandang melakukan pergerakan di internal kecamatan kedungkandang. Secara umum mayoritas pergerakan masyarakan menuju kecamatan Klojen, hal ini di karenakan kecamatan Klojen merupakat pusat kota, pemerintahan, perdagangan dan wisata.

\section{Kinerja Rute Eksisting Berbasis Kebutuhan Pergerakan dengan (GIS)}

Berdasarkan hasil buffer dalam perangkat lunak GIS dapat diketahui bahwa permintaan terbesar berasal dari kelurahan. 
Tabel 9. Kelurahan Dengan Permintaan Angkot Tertinggi

\begin{tabular}{cllc}
\hline No & Rute & Kelurahan & $\begin{array}{c}\text { Jumlah } \\
\text { Permintaan }\end{array}$ \\
\hline 1 & TST & Bumiayu & 21 \\
2 & ABH & Lowokwaru & 16 \\
3 & HM & Bandulan & 13 \\
\hline
\end{tabular}

Berdasarkan Tabel 9. dapat di jelaskan kelurahan Bumiayu merupakan kelurahan dengan permintaan angkot tertinggi pada rute TST yaitu $23,86 \%$ pengguna angkot berasal, kelurahan Lowokwaru merupakan kelurahan dengan permintaan angkot tertinggi pada rute $\mathrm{ABH}$ yaitu $19,51 \%$ pengguna angkot berasal dan kelurahan Bandulan merupakan kelurahan dengan permintaan angkot tertinggi pada rute HM yaitu $22.41 \%$ pengguna angkot berasal. Selain data permintaan terhadap angkot, dapat pula di ketahui data kinerja rute angkot, sosial ekonomi masyarakat, guna lahan dan lain sebagainya. Adapun hasil buffer $500 \mathrm{~m}$ kekanan dan 500m kekiri sepanjang rute angkot dapat di ketahui bahwa dari masyarakat pengguna angkot pada rute TST mayoritas berjarak 200m, pada rute $\mathrm{ABH}$ mayoritas berjarak $100 \mathrm{~m}$ dan pada rute HM mayoritas berjarak 200m yang artinya dari zona buffer telah melayani seluruh permintaan yang ada pada rutenya.

Perlunya Penentuan Pelayanan dari kecamatan atau wilayah dengan penduduk padat . Penentuan pelayanan angkutan kota dari kecamatan potensial yang dimaksud disini adalah kecamatan yang termasuk dalam hirarki serta kepadatan yang cukup tinggi. Akan tetapi dikarenakan luas cakupan dari buffer atau jangkauan sesuai standar yang dilakukan tidak terlayani secara keseluruhan, maka dibangun suatu Analisa baru yang kaitannya untuk mengakomodasi terhadap tindakan penyelesaian permasalahan dengan menempatkan hasil output berupa wilayah yang kurang terlayani tersebut untuk direncanakan penempatan angkutan tipe kecil. Alternatif moda yang masuk kedalam kategori adalah moda yang memilki kapasitas angkut yang kecil hingga sedang. Adapun alternatif moda yang mungkin diterapkan untuk jalur feeder yaitu ojek atau becak. Adapun jalan yang memungkinkan sebagai demand yang belum terfasilitasi angkutan feeder antara lain:

- Jalan parangtritis, Jalan Kaliurang barat, Jalan Krisno, Jalan Permadi, Jalan Bandulan Selatan,
Jalan Bandulan barat, Jalan Bandulan gang 3. Jalan Sumpil Gang 2

Dari data jalan di atas dapat dilihat wilayah yang belum terlayani angkutan feeder pada gambar berikut ini:

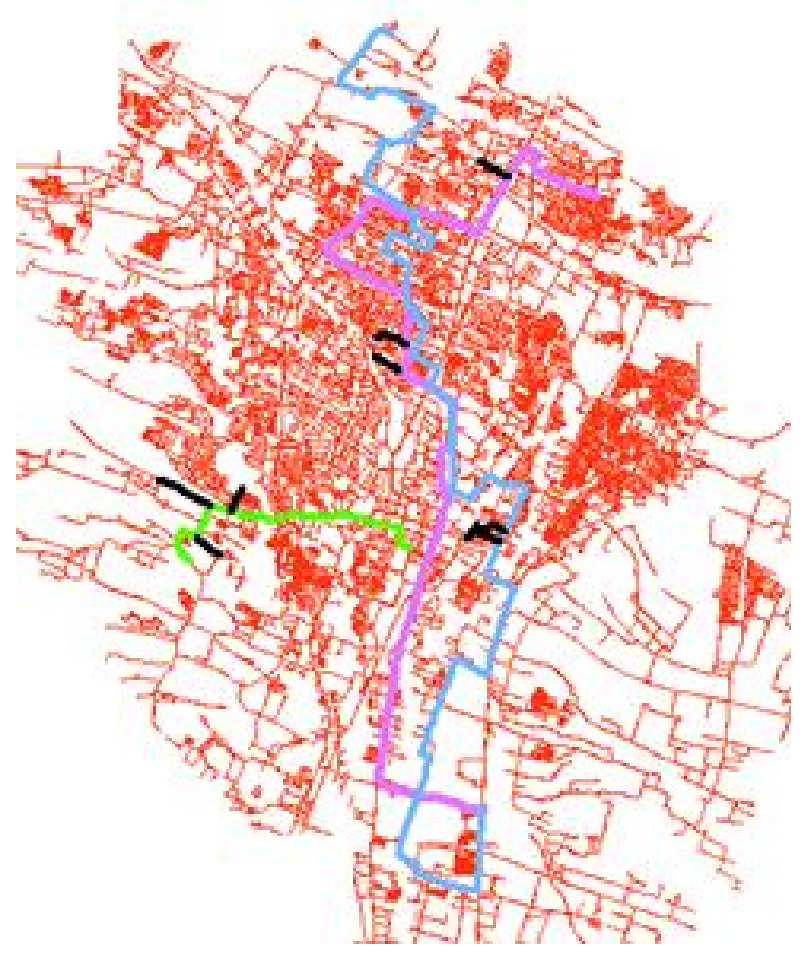

Gambar 6. Penentuan Rute Baru Untuk Angkutan Feeder

\section{KESIMPULAN DAN SARAN}

\section{Kesimpulan}

Dari analisis yang telah dilakukan maka didapatkan hasil penelitian sebagai berikut:

- Kinerja rute angkot berdasarkan 8 parameter yang digunakan mayoritas baik. Adapun 1 parameter yang masih di bawah standart yaitu nilai Load faktor yang masih rendah. Hal ini dikarenakan adanya ketidakpastian heeadway yang lama dan ketidak adanya kepastian angkot terutama pada hari-hari libur.

- Mayoritas pergerakan masyarakat dari Kecamatan Klojen menuju Kecamatan Klojen sebesar 43,00\%, mayoritas pergerakan masyarakat Kecamatan Lowokwaru munuju Kecamatan Blimbing sebesar 36,99\%, mayoritas pergerakan masyarakat Kecamatan Kedungkandang menuju Kecamatan 
Kedungkandang sebesar 53,70\%dan mayoritas pergerakan masyarakat Kecamatan Blimbing menuju Kecamatan Blimbing sebesar 40,45\%, Kecamatan Sukun menuju Kecamatan Klojen sebesar $67,11 \%$. Secara umum mayoritas pergerakan masyarakan menuju Kecamatan Klojen sebesar 35,97\% dari total pergerakan, hal ini dikarenakan Kecamatan Klojen merupakat pusat kota, pemerintahan, perdagangan dan jasa serta wisata.

- Secara spasial dari analisa GIS menunkkan bahwa Kelurahan Bumiayu merupakan kelurahan dengan permintaan angkot tertinggi pada rute TST yaitu $23,86 \%$ pengguna angkot berasal, kelurahan Lowokwaru merupakan kelurahan dengan permintaan angkot tertinggi pada rute $\mathrm{ABH}$ yaitu $19,51 \%$ pengguna angkot berasal dan kelurahan Bandulan merupakan kelurahan dengan permintaan angkot tertinggi pada rute HM yaitu $22.41 \%$ pengguna angkot berasal. Selain data permintaan terhadap angkot di setiap kelurahan berpenduduk padat, dapat pula di ketahui data kinerja rute angkot, sosial ekonomi masyarakat, guna lahan dan lain sebagainya. Adapun hasil buffer $500 \mathrm{~m}$ kekanan dan 500m kekiri sepanjang rute angkot dapat di ketahui bahwa dari masyarakat pengguna angkot pada rute TST mayoritas berjarak $200 \mathrm{~m}$, pada rute $\mathrm{ABH}$ mayoritas berjarak $100 \mathrm{~m}$ dan pada rute HM mayoritas berjarak $200 \mathrm{~m}$ yang artinya dari zona buffer telah melayani seluruh permintaan yang ada pada rutenya.

saran

Agar pelayanan rute angkutan kota dapat lebih baik dalam memenuhi kebutuhan permintaan akan angkutan umum serta kebutuhan pergerakan antar kawasan dalam wilayah Kota Malang, direkomendasikan kepada Pemerintah Kota Malang hal-hal sebagai berikut :

- Perlunya Penentuan Pelayanan dari kecamatan atau wilayah dengan penduduk padat . Penentuan pelayanan angkutan kota dari kecamatan potensial yang dimaksud disini adalah kecamatan yang termasuk dalam hirarki serta kepadatan yang cukup tinggi. Akan tetapi dikarenakan luas cakupan dari buffer atau jangkauan sesuai standar yang dilakukan tidak terlayani secara keseluruhan, maka dibangun suatu Analisa baru yang kaitannya untuk mengakomodasi terhadap tindakan penyelesaian permasalahan dengan menempatkan hasil output berupa wilayah yang kurang terlayani tersebut untuk direncanakan penempatan angkutan tipe kecil. Alternatif moda yang masuk kedalam kategori adalah moda yang memilki kapasitas angkut yang kecil hingga sedang. Adapun alternatif moda yang mungkin diterapkan untuk jalur feeder yaitu ojek atau becak. Adapun jalan yang memungkinkan sebagai demand yang belum terfasilitasi angkutan feeder antara lain:

- Jalan parangtritis

- Jalan Kaliurang barat

- Jalan Krisno

- Jalan Permadi

- Jalan Bandulan Selatan

- Jalan Bandulan barat

Jalan Bandulan gang 3

- Selain sebagai evaluasi rute angkutan kota berdasarkan pergerakan masyarakat, metode GIS dapat digunakan untuk penelitian lanjutan, antara lain berikut:

- Inventarisasi jaringan transportasi publik

Perencanaan perluasan jaringan jalan

- Kajian kawasan rawan kemacetan dan kecelakaan

- Kajian re-route atau penentuan rute baru

\section{DAFTAR PUSTAKA}

Aziz,M.M., 2005. Aplikasi Penentuan Rute Terbaik Berbasis Sistem Informasi Geografis. Jurnal Ilmiah Teknologi Informasi DINAMIK Volume X, No. 2, Mei 2005 : 7683. Stikubank Semarang

Black, J.A., 1981. Urban Transport Planning: Theory and Practice . London: Cromm Helm. Aini, A. Sistem Informasi Geografis Pengertian dan Aplikasinya. STMIK AMIKOM Yogyakarta. Yokyakarta.

ESRI, 1998, "Arcview Network Analyst", http:// www.esri.com/library/whitepapers/pdfs/ ana0498.pdf 
Wells G.R., 1975, Comprehensive Transport Planning, Charles Griffin \& Company Ltd., London.

Wira B.T., 2010. Penemuan Rute Terpendek Pada Aplikasi Berbasis Peta. Jurnal LONTAR KOMPUTER Vol.1 no. 1 2010. Universitas Udayanan. Bali 